\title{
DAMPAK COVID-19 TERHADAP PARIWISATA BALI DITINJAU DARI SEKTOR SOSIAL, EKONOMI, DAN LINGKUNGAN (SUATU TINJAUAN PUSTAKA)
}

\author{
A.A.A Ribeka Martha Purwahita ${ }^{1}$, Putu Bagus Wisnu Wardhana ${ }^{2}$, I Ketut Ardiasa ${ }^{3}$, \\ I Made Winia ${ }^{4}$ \\ Akademi Pariwisata Denpasar ${ }^{1,2,3,4}$ \\ Email: ribeka54@gmail.com ${ }^{1}$; baguswisnuwardhana@gmail.com ${ }^{2}$; \\ iketutardiasa39@gmail.com ${ }^{3}$; madewinia@akpar-denpasar.ac.id
}

Received: April 6, 2021 | Accepted: May 10, 2021 | Published: May 14, 2021

Permalink/DOI: https://doi.org/10.53356/diparojs.v1i2.29

\begin{abstract}
ABSTRAK
Dampak covid-19 sangat berpengaruh besar dalam berbagai sektor, khususnya bagi pelaku dan usaha pariwisata, apalagi Bali sangat mengandalkan sektor pariwisata. Dalam tulisan berupa kajian pustaka diuraikan lebih lanjut terkait permasalahan yang timbul, serta dampak perkembangan di sektor sosial, ekonomi dan lingkungan di masa pandemi covid-19 dengan mengidentifikasi wabah covid-19 secara global yang serta merta berpengaruh terhadap perkembangan pariwisata di Bali. Sesuai dengan Perda Provinsi Bali Nomor 2 tahun 2012, pariwisata Bali berlandaskan kebudayaan yang mampu menggerakkan potensi kepariwisataan dalam dinamika kehidupan lokal, nasional dan global. Saat ini perkembangan pariwisata Bali mengalami penurunan drastis bahkan sampai minus semenjak tahun 2020, yang melumpuhkan berbagai sektor khususnya di sektor ekonomi, terutama di bidang usaha pariwisata serta di bidang ketenagakerjaan, yang bisa dilihat pada pemutusan hubungan kerja (PHK) serta ditutupnya usaha-usaha pariwisata akibat penurunan permintaan dari wisatawan. Di sektor sosial terlihat dari perilaku dan kebiasaan masyarakat, pelaku pariwisata dan wisatawan. Aturan dari pemerintah untuk diterapkan di masyarakat sesuai dengan pencegahan penyebaran covid-19 lebih luas lagi dikenal dengan istilah 3M (mencuci tangan, memakai masker, menjaga jarak) serta CHSE (cleanliness, healthy, safety dan environment) yang meliputi program penerapan protokol kesehatan. Sektor lingkungan di masa pandemi ini memberikan dampak positif, mengingat aktivitas serta eksploitasi alam yang secara berlebihan kini dapat diminimalisir dan berkurang. Polusi yang diakibatkan oleh aktivitas pariwisata juga berkurang sehingga meningkatkan kualitas udara dan lingkungan. Melihat kondisi ini, pemerintah sangat memegang peran penting dalam mengeluarkan kebijakan bagi masyarakat dan komponen pariwisata (stakeholder) sehingga dapat tetap beraktivitas dan produktif dalam pergerakan di sektor ekonomi. Di sektor pariwisata, kebijakan pemerintah sangat dibutuhkan dan dapat direalisasikan segera dengan harapan kondisi pariwisata dapat berangsur-angsur pulih kembali.
\end{abstract}

Kata Kunci: Perkembangan Pariwisata, dampak covid-19, social, ekonomi, lingkungan 


\begin{abstract}
The impact of covid-19 has had a huge impact in various sectors, especially for tourism actors and businesses, especially since Bali relies heavily on the tourism sector. In writing in the form of a literature review, it is further described the problems that arise and the impact of developments in the social, economic and environmental sectors during the Covid-19 pandemic by identifying the global covid-19 outbreak which immediately affects the development of tourism in Bali. In accordance with the Bali Provincial Regulation No. 2 of 2012, Bali tourism is based on culture that is able to drive tourism potential in the dynamics of local, national and global life. Currently the development of tourism in Bali has decreased drastically even to minus since 2020, which has paralyzed various sectors, especially in the economic sector, especially in the tourism business sector as well as in the employment sector which can be seen in layoffs (PHK) and the closure of tourism businesses due to the decline. requests from tourists. In the social sector, it can be seen from the behavior and habits of the community, tourism actors and tourists. Rules from the government to be implemented in the community in accordance with the prevention of the spread of covid-19 are more widely known as $3 M$ (washing hands, wearing masks, maintaining distance) and CHSE (cleanliness, healthy, safety and environment) which includes a program for implementing health protocols. The environmental sector, which has an impact on the pandemic situation, has had a positive impact, given that the excessive and excessive exploitation of nature can now be minimized and reduced. Pollution caused by economic activity is also reduced, thus improving air quality and the environment. Seeing this condition, the government plays an important role in issuing policies for the community and the tourism component (stakeholders) so that they can remain active and productive in movements in the economic sector. In the tourism sector, government policies are urgently needed and can be realized immediately in the hope that tourism conditions will gradually recover.
\end{abstract}

Keywords: Tourism development, the impact of covid-19, social, economy, environment

\section{PENDAHULUAN}

Pandemi covid 19, dalam prosesnya membutuhkan waktu yang cukup lama untuk pemulihan dan mengharuskan masyarakat untuk memasuki tatanan hidup baru yang lebih sering disebut dengan era new normal. Penemuan vaksin oleh para ahli merupakan sebuah pencapaian yang sangat penting dan membutuhkan waktu yang cukup lama untuk bisa dilakukan vaksinasi secara merata kepada seluruh lapisan masyarakat. Hidup berdampingan dengan virus menjadi pilihan paling bijak untuk diterapkan saat ini, untuk tetap menjaga dan menggerakkan sedikit demi sedikit roda perekonomian. Di Bali, pariwisata merupakan salah satu sektor unggulan selain sektor pertanian dan industri kecil dan menengah. Pariwisata Bali telah tumbuh dan berkembang sedemikian rupa memberikan sumbangan yang besar terhadap pembangunan daerah dan masyarakat Bali baik secara langsung maupun tidak langsung (Merdeka, 2020).
Sektor ini menjadi salah satu langkah didalam menciptakan kesejahteraan masyarakat. Berbagai upaya dilakukan oleh Pemerintah Kabupaten/Kota yang ada di Bali telah bergiat mengembangkan potensipotensi lokal untuk membuat wisatawan domestik maupun mancanegara tetap tertarik mengunjungi pulau dewata. Tekanan terhadap sektor pariwisata yang disebabkan oleh penyakit akibat virus korona baru (Covid-19) diyakini berdampak pada perekonomian Bali. Badan Pusat Statistik Provinsi Bali menyebutkan, ekonomi Bali dalam tiga bulan pertama (triwulan I) 2020 tumbuh negatif, yakni $-1,14$ persen, dibandingkan kondisi tahun lalu pada triwulan I-2019. Pertumbuhan minus ini berada di luar dugaan dan ini disebabkan oleh merebaknya wabah virus corona yang mempengaruhi pergerakan masyarakat secara individu ataupun secara sosial, ekonomi dan lingkungan. Data tahun 2019 menunjukkan, sektor pariwisata 
berkontribusi 78 persen terhadap perekonomian Bali. Sangat jauh dari sektor pertanian yang hanya menyumbang 14,5 persen. Ketimpangan ini menyebabkan ketergantungan yang terlalu besar pada sektor pariwisata.

\section{KAJIAN LITERATUR}

\subsection{Dampak sosial ekonomi}

Menurut Wirateja (2014) Aspek ekonomi Usaha pengembangan pariwisata sangat mempengaruhi di berbagai sektor baik itu dari skala kecil, menengah, hingga skala besar, di mana antara satu sektor dengan lainnya saling mempengaruhi. Hal tersebut mampu memotivasi perekonomian di daerah kabupaten dan kota madya, yang pada akhirnya bisa membuka lapangan kerja dan dapat menahan terjadinya migrasi penduduk ke suatu tempat (kota) dengan mengoptimalkan sumber daya alam dan budaya yang dimiliki wilayah tersebut. Pariwisata membuka kesempatan untuk berusaha, khususnya disektor kerajinan, perhotelan, restoran dan usaha jasa lainnya dapat berpengaruh pada kesejahteraan masyarakat semakin meningkat, sehingga mampu mewujudkan suatu tatanan masyarakat yang adil dan makmur. Dalam perkembangan pariwisata tersebut sektor perekonomian masyarakat pun semakin meningkat, membuka lebih banyak kesempatan berusaha, membuka lapangan pekerjaan yang pada akhirnya berdampak pada lapisan masyarakat yang sejahtera baik itu secara lokal, nasional dan global. Apabila hal ini dikaitkan dengan dampak sosial ekonomi tentunya kegiatan pariwisata ini berpengaruh pada mata pencaharian dari masyarakat khususnya pada perubahan mata pencaharian mengingat sektor pariwisata sangat membuka peluang dalam peningkatan pendapatan serta penghasilan di setiap individu. Menurut Sugihamertha (2020),
Covid-19 berdampak besar hampir di semua aspek kehidupan termasuk sektor pariwisata karena meningkatnya pembatasan perjalanan, pembatalan acara besar dan keengganan untuk melakukan perjalanan internasional dan domestik. Untuk membatasi penyebaran pandemi Covid-19 dan mengatasi konsekuensi sosial-ekonomi tidak saja hanya pada perusahaan dengan skala besar tapi juga berdampak pada usaha kecil dan menengah (UKM).

Artikel ini menekankan kebijakan wabah Covid-19 terhadap sektor pariwisata dengan mempelajari data dan tindakantindakan yang telah dilakukan di sejumlah negara, untuk sebagian diusulkan agar dapat diterapkan di Indonesia. Hal ini sangat penting karena pariwisata menyangkut tenaga kerja yang banyak, dan peranannya secara ekonomi sedang didorong oleh pemerintah Indonesia. Perbedaannya dengan penelitian ini bahwa penanganan wabah covid-19 dibutuhkan kebijakan-kebijakan melalui tindakan yang tepat di berbagai sektor. Relevansinya adalah dengan terbentuknya kebijakan yang tepat akan membantu pemulihan ekonomi yang terpuruk.

\subsection{Dampak Lingkungan}

Menurut Darma (2020) adanya pandemi covid-19 memiliki dampak pada lingkungan yaitu dilihat dari penurunan polusi udara pada beberapa kota besar di Indonesia. Bahkan di beberapa kota internasional terutamanya kota dengan kondisi kegiatan yang padat, terjadi perubahan pada kondisi udara yang dialami. Alam pariwisata juga terdampak dari menurunnya kegiatan perjalanan pada pariwisata dimanapun berada. Terhentinya kegiatan pariwisata membuat ekosistem alam dapat memulihkan diri kembali dan terhindar dari eksploitasi manusia dalam 
industry pariwisata meskipun pemulihan yang dialami tidak dapat dirasakan secara instan. Diperlukan waktu yang lebih panjang untuk pemulihan alam pariwisata, pada kasus ini terlihat pada mulai meningkatkanya kembali kadar polusi udara pada kisaran bulan Juni 2020 diakibatkan kebijakan "New Normal" yang mulai diterapkan di beberapa kota besar, serta menyusul akan mengikuti pada industri pariwisata di Bali. Dampak lain dari adanya pandemi Covid-19 ini di antaranya adalah pengurangan tenaga kerja pada sektor industri pariwisata yang berakibat pada menurunnya perekonomian masyarakat, bergesernya minat wisatawan dengan melaksanakan tren ekowisata dalam melakukan wisata di mana sebelumnya beberapa wilayah termasuk Bali yang menerapkan mass tourism, serta timbulnya banyak masalah ekonomi yang diakibatkan banyaknya pengurangan tenaga kerja yang terjadi. Penurunan polusi udara semakin baik selama masa awal pandemi Covid-19 terjadi. Terlihat pada aplikasi bahwa tingkat kelayakan dari polusi udara yang berkurang. Pada Pulau Bali terdapat perbaikan kualitas udara yang semakin membaik terutama dari berkurangnya kendaraan yang melakukan aktivitas selama masa pembatasan berkegiatan selama pandemi Covid-19 tersebut. Pulau Bali yang menggantungkan sebagian perekonomian pada industri pariwisata, secara nyata juga terdampak dari adanya Covid-19 tersebut. Terlihat dari semakin bersih dan cerahnya udara di Pulau Bali. Beberapa tempat yang cukup jauh juga semakin jelas dapat melihat keberadaan Gunung Agung sebagai gunung tertinggi di Pulau Bali di mana dampaknya sangat positif bagi keberlangsungan ekologi. Pada beberapa tempat di dunia, pembatasan kegiatan masyarakat berpengaruh pula pada kualitas udara di beberapa tempat yang semakin cerah dan baik. Berkurangnya kendaraan, terutama dari industri pariwisata, menjadi suatu momen bagi alam didalam pemulihan dan terhindar sejenak dari eksploitasi manusia, meskipun pandemi covid ini berimbas pada penurunan perekonomian dan pada sektor lainnya khususnya pariwisata di Bali.

Menurut Suryani (2020), jauh sebelum terjadinya pandemi Covid-19, berbagai negara di dunia telah dihadapkan pada permasalahan lingkungan global, yakni perubahan iklim. Penanganan perubahan iklim merupakan salah satu dari 17 tujuan global yang tersusun dalam Agenda Pembangunan Berkelanjutan 2030. Pandemi Covid-19 telah berdampak pada capaian tujuan global tersebut. Tulisan ini bertujuan mengkaji dampak pandemi Covid-19 pada lingkungan global. Parameter lingkungan yang cenderung membaik saat pandemi antara lain penurunan emisi $\mathrm{CO} 2$ dan $\mathrm{NO} 2$, peningkatan kualitas udara perkotaan, serta terjaganya keanekaragaman hayati. Sedangkan parameter persampahan dan kehutanan menunjukkan adanya penurunan. Membaiknya beberapa parameter lingkungan tersebut dikhawatirkan hanya bersifat sementara dan akan kembali memburuk jika aktivitas masyarakat serta ekonomi berjalan normal kembali. Oleh karena itu, pembangunan tidak saja dilihat dari sektor ekonomi, tetapi juga harus memperhatikan faktor lingkungan jika ingin mencapai pembangunan yang berkelanjutan serta berkesinambungan di berbagai sektor, maka harus mengedepankan prinsip ramah lingkungan.

\section{METODE PENELITIAN}

Metode yang digunakan adalah dengan menggunakan kajian pustaka dari hasil-hasil penelitian terdahulu serta media sosial yang mengangkat tema dan topik mengenai perkembangan Covid-19 berpengaruh pada 
sektor sosial, ekonomi dan lingkungan di nasional dan lokal.

\section{HASIL DAN PEMBAHASAN}

\subsection{Dampak Sosial Ekonomi Wabah Covid-19 terhadap Perkembangan Pariwisata Nasional dan Bali}

Peranan sektor pariwisata nasional semakin penting dilihat dari perkembangan dan kontribusi yang diberikan sektor pariwisata melalui penerimaan devisa, pendapatan daerah, pengembangan wilayah, maupun dalam penyerapan investasi dan tenaga kerja serta pengembangan usaha yang tersebar di berbagai pelosok wilayah di Indonesia. Sektor pariwisata mempunyai pengaruh terhadap perekonomian suatu negara melalui beberapa faktor. Pertama, sektor pariwisata sebagai penghasil devisa untuk memperoleh barang modal yang dipakai dalam proses produksi. Kedua, pengembangan pariwisata menstimulus pembangunan infrastruktur. Ketiga, pengembangan sektor pariwisata mendorong perkembangan sektor-sektor ekonomi lainnya. Keempat, pariwisata ikut berkontribusi terhadap peningkatan kesempatan kerja dan pendapatan. Kelima, pariwisata dapat menyebabkan positive economies of scale (Yakup, 2019).

Bali sangat bertumpu pada sektor pariwisata, sebelum Covid-19 sektor pariwisata menyumbang sampai $53 \%$ terhadap perekonomian Bali. Pengaruh pandemi Covid-19 saat ini sangat berdampak signifikan melampui bom Bali dan meletusnya Gunung Agung. Namun, pemulihan ekonomi mulai tampak walau sangat perlahan semenjak dibukanya new normal pada libur panjang akhir Oktober lalu, tingkat hunian kamar hotel mulai menunjukkan peningkatan sekitar 25-30\%, yang didominasi oleh wisatawan domestik atau lokal. Data menunjukkan bahwa mencapai angka $53 \%$ ekonomi Bali ditopang oleh sektor pariwisata. Apabila dilihat dari sumber tenaga kerja, Hal ini juga berdampak bahwa seberapa besar lapangan kerja diserap dari sektor pariwisata. Untuk membangun lapangan kerja di Bali, Pemerintah Provinsi Bali harus membangkitkan kembali pariwisata Bali. Untuk target pasar yang dibuka dan digarap dalam waktu dekat ini adalah wisatawan domestik terlebih dahulu. Karena daya pemulihan wisatawan domestik jauh lebih cepat daripada wisatawan mancanegara. Hal ini juga disebabkan beberapa Negara yang hampir secara keseluruhan terdampak wabah Covid-19 ini, belum memberikan masyarakatnya untuk melakukan perjalanan ke Negara lain termasuk aktivitas berwisata. Bisa dikatakan bahwa pemulihan kunjungan wisman diproyeksikan baru akan kembali 50\% di tahun 2021 dan pulih secara normal pada tahun 2022. Dengan demikian maka ekonomi Bali akan kembali pada posisi normalnya tahun 2022. Pertumbuhan ekonomi tahun 2020 diperkirakan dalam kisaran $\quad-8 \% \quad$ s.d. $\quad-9 \%$ sedangkan pertumbuhan ekonomi tahun 2021 diperkirakan dalam kisaran 4\% - 5\%.

Seperti pernyataan yang dipaparkan dalam salah satu video yang diunggah di kanal Youtube oleh Nas Das Official yang berjudul Be Careful of The Next 2 Years, yaitu pernyataan yang mengungkapkan Covid-19 tak hilang di muka bumi setidaknya selama 2 tahun yang berdampak pada kondisi sosial yaitu kemiskinan dan kehilangan pekerjaan, maka kedua hal tersebut bisa saja terjadi di Indonesia berdasarkan pemaparan studi berikut. Menurut studi yang dilakukan oleh Suryahadi et.al (2020) memprediksikan 
tingkat kemiskinan rata-rata Indonesia akan meningkat di akhir tahun 2020, sehingga peningkatan tersebut akan menyebabkan sekitar 8 juta penduduk akan mengalami kemiskinan baru akibat wabah ini. Data estimasi ini didapatkan berdasarkan data Susenas bulan Maret dan September 2019. Selain itu, terdapat data tingkat kemiskinan pada tahun 2006 dan 2007 untuk melihat pola yang ada, karena di tahun tersebut terjadi lonjakan kemiskinan sebagai akibat naiknya harga minyak dunia. Sehingga diprediksi akhir tahun nanti tingkat kemiskinan rata-rata Indonesia akan mencapai 9,7\% yang sebelumnya pada September 2019 mencapai 9,22\%. Prediksi peningkatan persentase kemiskinan juga berdasarkan pertumbuhan ekonomi. Jika Pertumbuhan ekonomi menurun $1 \%$ maka setidaknya akan menambah sekitar 1,4\% persentase kemiskinan. Tak hanya berdasarkan data estimasi, keadaan di lapangan pun juga digambarkan demikian. Sekitar 2,8 juta orang telah kehilangan pekerjaan, dan proyeksi yang ada menunjukkan setidaknya 5,2 juta penduduk lainnya akan kehilangan pekerjaan saat pandemi menyebar.

Pada industri pariwisata Indonesia, virus ini mulai memberikan dampak pada awal tahun 2020 yang mana banyak wisatawan membatalkan rencana perjalanannya terutama wisatawan mancanegara yang berasal dari negeri Cina di mana negara ini adalah asal muasal virus ini pertama kali terjadi. Bagi pelaku pariwisata, hal ini adalah pukulan yang sangat telak mengakibatkan hampir 90\% karyawan dirumahkan. Keputusan ini sangat sulit dari sisi kemanusiaan, tetapi juga harus melihat realistas kondisi yang terjadi. Pemulihannya pun membutuhkan waktu yang cukup lama, apabila dilihat dari perekonomian Indonesia secara global, serta perekonomian pariwisata hingga minus dan banyaknya jumlah tenaga kerja yang dikeluarkan dari perusahaan, khususnya bagi Bali yang perekonomian dan penduduknya tergantung dari pariwisata. Tentunya hal ini tidak bisa dibiarkan begitu saja, namun diperlukan strategi yang tepat baik itu dari pemerintah pusat maupun pemerintah. Bali untuk mengupayakan sektor pariwisata agar segera pulih dan berjalan normal kembali. Pelaku pariwisata di Indonesia harus optimis keadaan seperti ini segera cepat berakhir karena mayoritas penduduk indonesia menggantungkan hidupnya dari sektor ekonomi pariwisata, efek berantai ini mengakibatkan banyak sektor lumpuh. Dampak pandemi Covid-19 pada perekonomian Bali yang sangat bergantung pada sektor pariwisata semakin berdampak signifikan terhadap kedatangan wisatawan mancanegara (wisman) langsung ke Bali. Pada bulan Agustus 2020, jumlah wisman tercatat hanya 22 kunjungan, turun hampir 100,00 persen $(-99,996$ persen $)$ dibandingkan catatan jumlah wisman di bulan Agustus 2019 yang sebanyak 606.412 kunjungan. Bila dibandingkan dengan catatan bulan Juli 2020, capaian wisman di bulan Agustus 2020 juga tercatat menurun 53,19 persen. Sebagian besar wisman pada bulan Agustus 2020 datang melalui pintu udara (bandar udara) yakni sebanyak 12 kunjungan, sementara wisman yang melalui pintu laut (pelabuhan) tercatat sebanyak 10 kunjungan. Secara kumulatif pada periode Januari-Agustus 2020, kunjungan wisman ke Bali tercatat sebanyak 1.050.161 kunjungan. Jumlah ini turun sedalam $-74,18$ persen dibandingkan dengan capaian periode Januari-Agustus 2019 (y on y) yang tercatat sebanyak 4.066.517 kunjungan. Kalau diurutkan berdasarkan sumbangan terhadap total secara kumulatif, maka wisman kebangsaan Australia tercatat sebagai 
wisman dengan sumbangan terbesar yaitu 21,17 persen, kemudian disusul dengan urutan berikutnya wisman kebangsaan Tiongkok (11,15 persen), India (6,41 persen), Rusia (5,39 persen), Jepang (4,58 persen), Amerika Serikat (4,47 persen), Inggris (4,43 persen), Korea Selatan (4,05 persen), Malaysia (2,94 persen), dan Perancis (2,79 persen). Dari sepuluh kebangsaan wisman selama periode Januari Agustus 2020, jika diurai menurut besarnya perubahan dibandingkan periode yang sama tahun sebelumnya, maka wisman berkebangsaan. Tiongkok tercatat mengalami penurunan paling dalam yaitu 86,07 persen, disusul oleh Perancis -78,49 persen, dan wisman berkebangsaan Inggris 75,10 persen. Selengkapnya rincian kedatangan wisman menurut kebangsaan secara kumulatif ditunjukkan pada table 2.

\section{Tabel 2}

10 Negara Utama Kedatangan Wisman Menurut Kebangsaan Januari - Agustus 2019 dan Januari - Agustus 2020

\begin{tabular}{|c|c|c|c|c|c|c|c|}
\hline No. & Kebangsaan & $\begin{array}{l}\text { Bandara } \\
\text { (Kunjungan) }\end{array}$ & $\begin{array}{l}\text { Pelabuhan } \\
\text { Laut } \\
\text { (Kunjungan } \\
\text { ) }\end{array}$ & $\begin{array}{c}\text { Total } \\
\text { (Kunjungan } \\
\text { ) }\end{array}$ & $\begin{array}{c}\text { Persentase } \\
(\%)\end{array}$ & $\begin{array}{c}\text { Wisman Jan- } \\
\text { Agustus } 2019 \\
\text { (Kunjungan) }\end{array}$ & $\begin{array}{c}\text { Perubahan } \\
\text { Wisman Jan- } \\
\text { Agustus } 2020 \text { Thd } \\
\text { Jan-Agustus } 2019 \\
(\%)\end{array}$ \\
\hline 1 & AUSTRALIA & 217.981 & 4.378 & 222.359 & 21,17 & 781.307 & $-71,54$ \\
\hline 2 & TIONGKOK & 116.971 & 104 & 117.075 & 11,15 & 840.290 & $-86,07$ \\
\hline 3 & INDIA & 67.361 & 4 & 67.365 & 6,41 & 243.189 & $-72,30$ \\
\hline 4 & RUSIA & 56.536 & 29 & 56.565 & 5,39 & 87.755 & $-35,54$ \\
\hline 5 & JEPANG & 47.416 & 729 & 48.145 & 4,58 & 167.276 & $-71,22$ \\
\hline 6 & $\begin{array}{l}\text { AMERIKA } \\
\text { SERIKAT }\end{array}$ & 46.228 & 703 & 46.931 & 4,47 & 178.673 & $-73,73$ \\
\hline 7 & INGGRIS & 45.466 & 1.044 & 46.510 & 4,43 & 186.788 & $-75,10$ \\
\hline 8 & KOREA SELATAN & 42.433 & 54 & 42.487 & 4,05 & 132.532 & $-67,94$ \\
\hline 9 & MALAYSIA & 30.914 & 10 & 30.924 & 2,94 & 109.771 & $-71,83$ \\
\hline 10 & PERANCIS & 29.290 & 15 & 29.305 & 2,79 & 136.230 & $-78,49$ \\
\hline 11 & Lainnya & 340.677 & 1.818 & 342.495 & 32,61 & 1.202 .706 & $-71,52$ \\
\hline \multicolumn{2}{|c|}{ Jumlah } & 1.041 .273 & 8.888 & 1.050 .161 & 100,00 & 4.066 .517 & $-74,18$ \\
\hline
\end{tabular}

Sumber: BPS Provinsi Bali, 2020

Berikut ini beberapa usaha pariwisata yang terkena dampak Covid 19 di sektor ekonomi.

\section{Biro Perjalanan Wisata}

Biro perjalanan Wisata adalah salah satu sektor yang terdampak langsung akibat virus corona ini yang mana banyak pembatalan rencana perjalanan wisata yang sudah diagendakan jauh hari sebelumnya, akhirnya dibatalkan karena adanya virus ini. Presentase pembatalan yang diakibatkan virus ini hampir menyentuh angka 100\% yang mengakibatkan banyak biro perjalanan wisata juga seakan akan mati sepenuhnya dalam hal perekenomian dan terpaksa merumahkan keseluruhan karyawannya karena masih banyak beban juga yang harus ditanggung dari pembatalan rencana perjalananan yang diakibatkan dan juga masih banyak faktor finansial lain yang ditimbulkan akibat Covid-19. Hal ini mengalami keterpurukan bagi biro 
perjalanan wisata yang ada di Bali mengingat beberapa Negara yang masih lockdown disamping juga bandara udara dan penerbangan ditutup.

\section{Hotel}

Sama halnya dengan penurunan jumlah wisatawan dan hampir nihil ini juga berdampak pada jumlah hunian kamar hotel. Yaitu bisa dilihat dari data jumlah wisatawan mancanegara (wisman) ke Provinsi Bali pada bulan Agustus 2020 mengalami penurunan sedalam $-53,19$ persen dibandingkan dengan catatan bulan Juli 2020 ( $m$ to $m$ ). Bila dibandingkan dengan bulan Agustus 2019 (y on y), jumlah wisman ke Bali tercatat turun hampir 100 persen (-99,996 persen). Tingkat Penghunian Kamar (TPK) hotel berbintang pada bulan Agustus 2020 tercatat sebesar 3,68 persen, naik 1,11 poin dibandingkan TPK bulan Juli 2020 ( $\mathrm{m}$ to $\mathrm{m}$ ) yang tercatat sebesar 2,57 persen. Jika dibandingkan bulan Agustus 2019 (y on y) yang mencapai 67,10 persen, tingkat penghunian kamar pada bulan Agustus 2020 tercatat turun sedalam -63,42 poin. Menurut klasifikasi hotel berbintang,
TPK hotel berbintang 2 tercatat 4,45 persen yang merupakan TPK tertinggi pada bulan Agustus 2020 di antara kelas hotel berbintang lainnya. TPK terendah tercatat pada hotel berbintang 1 yang hanya mencapai 0,10 persen. Bila dibandingkan dengan capaian bulan Juli 2020 (m to m), penurunan TPK tercatat pada hotel berbintang 1 dengan penurunan -2,61 poin, sedangkan TPK hotel berbintang 5 tercatat mengalami peningkatan setinggi 1,78 poin, yang merupakan peningkatan tertinggi di antara hotel berbintang. 4. Berita Resmi Statistik Provinsi Bali No. 60/10/51/Th. XIV, 1 Oktober 2020 Bila dibandingkan dengan TPK Agustus 2019 (y on y), TPK Agustus 2020 mengalami penurunan - 63,42 poin. Penurunan TPK ( $y$ on $y$ ) tercatat pada seluruh kelas hotel berbintang, dengan penurunan terdalam tercatat pada hotel berbintang 4 sedalam $-70,56$ poin dan penurunan terendah tercatat pada hotel berbintang 1 sedalam $-41,88$ poin.

\section{Tabel 2}

TPK Menurut Klasifikasi Bintang di Bali

Agustus 2019, Juli 2020 dan Agustus 2020

\begin{tabular}{ccccccc} 
No. & $\begin{array}{c}\text { Klasifika } \\
\text { si } \\
\text { Bintang }\end{array}$ & $\begin{array}{c}\text { Tingkat Penghunian Kamar (TPK) (\%) } \\
\text { Agustus }\end{array}$ & $\begin{array}{c}\text { Perubahan } \\
\text { Agustus } \\
2020^{*} \text { thd } \\
\text { Juli 2020 } \\
\text { (Poin) }\end{array}$ & $\begin{array}{c}\text { Perubahan } \\
\text { Agustus202 } \\
0^{*} \text { thd }\end{array}$ \\
$\begin{array}{c}\text { Agustus } \\
2020 \text { (Poin) }\end{array}$ \\
\hline 1 & Bintang 1 & 41,98 & 2,71 & 0,10 & $-2,61$ & $-41,88$ \\
2 & Bintang 2 & 57,48 & 3,29 & 4,45 & 1,16 & $-53,03$ \\
3 & Bintang 3 & 63,20 & 3,22 & 4,27 & 1,05 & $-58,93$ \\
4 & Bintang 4 & 73,93 & 2,89 & 3,37 & 0,47 & $-70,56$ \\
5 & Bintang 5 & 67,53 & 1,67 & 3,46 & 1,78 & $-64,07$ \\
Seluruh & Bintang & 67,10 & 2,57 & 3,68 & 1,11 & $-63,42$
\end{tabular}

*) Pendataan dalam masa pengaturan penjarakan sosial (social distancing)

Sumber: BPS Provinsi Bali, 2020

Hotel menjadi sektor yang paling parah juga dihantam oleh pandemi virus Covid-19 ini yang mana banyak hotel yang mengandalkan pendapatan dari kerjasama dengan biro perjalanan wisata. Dengan tidak adanya dukungan dari biro perjalanan wisata, 
hotel seakan akan lumpuh dari aktivitas pemesanan yang memberi sumbangan pendapatan hotel sebesar $60 \%$. Sekarang ini banyak hotel yang sudah merumahkan hampir 99\% karyawan tanpa gaji dan menutup operasional hotel sepenuhnya untuk memotong kerugian yang lebih banyak lagi akibat tidak adanya pemasukan dan tingkat okupansi hotel yang rendah dan tidak sebanding dengan pendapatan yang diterima. dapat segera pulih dengan cepat.

\section{Restoran/Rumah Makan Wisata}

Restoran juga terkena imbas dari pandemi covid-19 ini yang mana banyak restoran yang terpaksa menutup operasional karena tidak adanya pembeli yang berkunjung akibat ditutupnya tempat tempat wisata di daerah masing masing, dengan tidak adanya dukungan dari biro perjalanan dan tempat wisata banyak restoran yang berpikiran realistis untuk menutup restoran miliknya. Sebagai contoh banyak restoran wisata di Bali yaitu tepatnya di kawasan pantai jimbaran, pantai kedonganan menutup restoran karena tidak adanya wisatawan yang berkunjung ke Bali baik itu wisatawan lokal dan mancanegara. Ini sebenarnya pilihan yang sangat realistis karena dengan ditutupnya tempat wisata di Bali berarti juga tidak akan adanya wisatawan yang akan datang berkunjung baik itu lokal maupun mancanegara. Tidak hanya di Bali, di Kota pariwisata seperti Malang, Yogyakarta juga banyak restoran melakukan hal serupa sehingga pemilik restoran juga merumahkan semua karyawannya.

\section{Toko Pusat Oleh-Oleh dan Cenderamata}

Pusat oleh oleh juga terkena dampak langsung virus corona ini karena dengan ditutupnya tempat wisata di daerah daerah mengakibatkan tidak adanya wisatawan yang datang sehingga mengakibatkan pusat oleh oleh juga banyak yang tutup dan
Bahkan di kota kota besar, yang tingkat pendapatannya hanya mengandalkan sektor pariwisata, banyak isu yang berkembang yaitu banyak hotel yang dijual, khususnya di Bali beberapa hotel telah dijual dan beberapa juga telah dialihfungsikan mengingat biaya operasional yang cukup tinggi dan tidak mampu menutup kerugian yang ditimbulkan. Sekarang ini bagi pemilik hotel atau investor hotel hanya berharap perekonomian di dunia merumahkan karyawannya. Seperti contoh di Bali yaitu Krisna pusat oleh oleh khas Bali yang terpaksa menutup semua outlet miliknya dan merumahkan hampir $80 \%$ karyawannya. Hal ini terjadi karena tidak ada wisatawan lokal maupun mancanegara yang berkunjung di Bali. Wisatawan lokal yang mana kita tau sendiri sekarang di Indonesia dilakukan pembatasan perjalanan dalam bentuk apapun. Pusat oleh oleh juga memegang peranan bagi UMKM yang mensuplai barang yang dijual oleh pusat oleh-oleh. Karena itu dengan ditutupnya pusat oleh oleh, UMKM juga merasakan dampaknya juga dan menjadi faktor kerugian yang sangat beruntun bagi pihak UMKM dan beberapa vendor yang bekerja sama dengan pusat oleh oleh.

\section{Transportasi (Darat, laut dan udara)}

Transportasi sangat berperan penting dalam aktivitas pariwisata, karena segala aktivitas dan perjalanan sangat membutuhkan transportasi baik itu lintas daerah dan antar negara. Perusahaan penerbangan, rental mobil dan transportasi umum apapun merupakan pihak yang sangat terpukul karena kejadian ini, mengingat sudah banyak agen perjalanan dan biro perjalanan wisata yang membatalkan semua agenda perjalanannya untuk mengunjungi suatu destinasi wisata mapun untuk tujuan yang beranekaragam lainnya. presentasi pembatalan sampai saat ini-Juni 2020 sudah mencapai $100 \%$. Hal ini tidak bisa dihindari 
karena banyak masyarakat yang juga takut akan penularan virus ini. Berkaca dari kejadian yang sedang terjadi banyak pengusaha rental mobil dan biro perjalanan wisata yang sedang kesusahan untuk membayar cicilan kendaraan yang masih tetap jalan sampai saat ini, ditutupnya perusahaan transportasi yang dikelola pihak swasta dan perusahaan penerbangan yang merumahkan hampir semua karyawannya, hal ini sudah tidak bisa terhindarkan.

Dalam kasus di Indonesia, saat ini, tercatat lima maskapai nasional yang mengoperasikan penerbangan reguler dan carter dari atau ke Cina, yakni Garuda Indonesia, Citilink, Batik Air, Lion Air, serta Sriwijaya Air. Sebagai catatan, grup Garuda Indonesia setidaknya memiliki jadwal penerbangan hingga 40 penerbangan per minggu untuk tujuan Cina. Diperkirakan pendapatan sektor transportasi udara global tahun 2020 turun sebesar US\$252 miliar atau merosot sebesar 44 persen jika dibandingkan dengan tahun 2019 (National Geographic, 2020). Grafik menunjukkan penurunan pendapatan di sektor transportasi udara.

Berdasarkan perhitungan Badan Pusat Statistik (BPS,2020), jumlah kunjungan wisman bulan Maret 2020 hanya sebesar 470.900 wisman. Angka ini mengalami penurunan sebesar minus 45,50 persen terhadap bulan Februari 2020 dan penurunan sebesar 64,11 persen terhadap bulan Maret 2019. Penurunan ini tentu saja dirasakan langsung oleh sektor transportasi penerbangan internasional.

Garuda Indonesia, Lion Air Group pun memiliki jadwal sebanyak 44 penerbangan per minggu dengan rute Indonesia-Cina. Secara agregat, rute Indonesia-Cina menyumbang 35 hingga 40 persen terhadap total penerbangan internasional Indonesia. Sejak diberlakukannya kebijakan ini, dikutip dari Kontan.com (2020), PT Angkasa Pura
(AP) I mengestimasi kerugian pembatalan penerbangan akibat virus corona (Covid-19) dari China ke Bali senilai Rp48 miliar sepanjang periode Januari - Februari 2020.

\section{Karyawan Pariwisata}

Karyawan yang dimaksudkan disini adalah sumber daya manusia (SDM) yang berhubungan langsung dengan dunia pariwisata seperti karyawan travel agent, karyawan hotel, karyawan restoran, karyawan pusat oleh oleh, karyawan rental mobil, sopir, tour leader (TL), tour guide (TG) yang semuanya menggantungkan hidupnya kepada usaha usaha yang berhubungan langsung dengan industri pariwisata. Di sektor pariwisata sebesar 20 juta jiwa. Sungguh angka yang sangat miris ketika hal ini kurang diperhatikan oleh pemerintah dan hal ini mungkin diluar prediksi dari kementrian tenaga kerja.

Dari beberapa penjelasan di atas, memang sudah tidak bisa dihindari lagi berbagai kondisi yang muncul, walaupun berbagai harapan bahwa kondisi ini bisa pulih kembali dan normal. Dalam artian wabah Covid-19 ini segera berakhir. Mengingat sektor pariwisata adalah penyumbang devisa terbesar di Negara Kesatuan Republik Indonesia dan harapan akan tetap menjadi penyumbang devisa terbesar.

\subsection{Dampak Lingkungan dari Wabah Covid-19 terhadap Pariwisata Bali}

Selain berdampak pada cara hidup masyarakat, adanya pandemi virus Corona juga turut memberi dampak pada lingkungan. Akhir-akhir ini, masyarakat dapat melihat berbagai visual yang menunjukkan pemandangan tidak biasa, seperti cuaca cerah tanpa dihalangi asap polusi udara, jalanan yang tampak sepi tanpa kemacetan dan salah satu yang menarik 
perhatian masyarakat dunia adalah jernihnya kanal-kanal Sungai di Venesia, yang biasanya ramai dikunjungi turis. Sepinya Pantai Kuta dari kunjungan wisatawan bahkan hampir seluruh kawasan wisata pulau Bali, secara tidak langsung telah memberikan kesempatan alam semesta untuk dapat memulihkan kondisi seperti sediakala di mana sebelumnya banyak mengalami pencemaran, yang tidak lain adalah dampak lingkungan sebagai akibat pariwisata.

Di pulau Bali, dampak dari pandemi Covid-19 berimbas terhadap sektor pariwisata, yang secara langsung berkontribusi terhadap menurunnya volume sampah khususnya di daerah wisata. Menurut Gubernur Bali, Wayan Koster, permasalahan sampah merupakan masalah klasik bagi masyarakat Bali. Alam pulau Dewata rusak karena sampah. Terlebih sebagai daerah tujuan wisata, sampah juga dianggap sebagai momok (merdeka.com, 2021).

Pandemi Covid-19 juga berdampak pada perbaikan kualitas udara di pulau Bali karena aktivitas pariwisata yang merosot dan pembatasan mobilitas kendaraan bermotor, yang dilaksanakan oleh pemerintah untuk mengendalikan penyebaran Covid-19. Pandemi Covid-19 telah mempengaruhi sejumlah aspek kehidupan. Banyak negara mulai menerapkan sejumlah kebijakan untuk membatasi segala bentuk aktivitas (lockdown). Kebijakan lockdown ini membawa dampak nyata terhadap membaiknya kualitas udara khususnya di perkotaan. Namun, permasalahan baru muncul berupa meningkatnya sampah medis dan plastik terkait dengan kebutuhan di masa pandemi ini. Perlu adanya kebijakan strategis dari pemerintah dan masyarakat untuk memilih opsi yang lebih ramah lingkungan dalam menghadapi permasalahan lingkungan di masa pandemi Covid-19. Karena permasalahan pada lingkungan juga penting dan membutuhkan upaya masif dan konsisten untuk mencegah kerusakan lingkungan. Namun, jika penanganan serta pengendalian tidak cepat, maka akan berdampak serius bagi alam itu sendiri.

\section{PENUTUP}

Berbagai upaya terus dilakukan dengan harapan Bali mendapatkan 'trust' kepercayaan dari wisatawan sebagai destinasi wisata yang layak untuk dikunjungi. Kesempatan ini hanya dapat diraih, selama dapat memberi jaminan kepada para wisatawan bahwa kondisi aman dari resiko terjangkit Covid-19 selama berada di Bali. Oleh karena itu, implementasi protokol kesehatan di semua sektor harus menjadi fokus bersama. Secara ekonomi dan social, dari data kunjungan wisatawan mancanegara dari Januari hingga Agustus 2020 mengalami penurunan $-74,18 \%$, disamping penurunan pada jumlah kunjungan, jumlah hunian kamar/hotel, jumlah penggunaan transportasi serta menurunnya pendapatan dari usaha pariwisata yang terkait.

Perkembangan pariwisata di masa pandemi, yang menyebabkan keterpurukan perlu segera ditangani oleh pemerintah dengan mengeluarkan kebijakan secara holistik dalam menangani situasi ini. Akibat dari jumlah tenaga kerja yang mengalami pengangguran tentu akan berakibat dalam peningkatan jumlah angka kemiskinan di Bali.

Bali yang sangat mengandalkan sektor pariwisata perlu membuka sektor lainnya yang masih melekat pada masyarakat Bali seperti pertanian, perdagangan dan nelayan. Masyarakat diberikan pemahaman untuk kembali secara perlahan membuka peluang 
usaha di sektor lainnya, sehingga perekonomian tidak seterusnya mengalami permasalahan yang panjang. Namun, hal ini tidak serta merta meninggalkan sektor pariwisata. Ini adalah waktu yang tepat untuk meningkatkan diri dalam pembekalan ilmu, menambah keterampilan dan pendidikan untuk terus menerus mengasah diri, sehingga nantinya siap jika sektor pariwisata dibuka dan normal kembali.

Sektor sosial erat kaitannya dengan tetap menerapkan protokol kesehatan sesuai anjuran pemerintah; mengubah kebiasaan hidup agar lebih sehat, bersih dan tetap aktif beraktivitas. Selanjutnya, sektor lingkungan menekankan pada masyarakat, wisatawan dan pelaku pariwisata untuk meningkatkan kesadaran memelihara dan menjaga kelestarian alam, sehingga bisa dimanfaatkan, tidak hanya untuk saat ini, tetapi juga di masa mendatang.

\section{DAFTAR PUSTAKA}

Badan Statistik Provinsi Bali No. 60/10/51/Th. XIV, 1 Oktober 2020

Darma, I Gusti Ketut Indra Pranata \& Kristina Ni Made Rai. (2020). "Pemulihan Fungsi Alam Pariwisata Ditengah Pandemi Covid-19". Khazanah Ilmu: Jurnal Pariwisata dan Budaya, 11(2), 101 - 108. Tersedia dari: https:// DOI: 10.31294/khi. v11i2.8480 0086.

LPEM UI. (2020). "Trade and Industry Maret 2020". Jakarta: LPEM UI

Sitimorang, Anggun P. (2020). "Pemerintah Soal Kenormalan Baru: Hidup Berdampingan Dengan Covid-19 Sementara Waktu”. Berita (online), Edisi 3 Juni 2020. Tersedia dari: https://www.merdeka.com/uang/pemerintah -soal-kenormalan-baru-hidupberdampingan-dengan-covid-19-sementarawaktu.html?page $=1$
Kadafi, Moh. (2021). "Wayan Koster Akui Alam Bali Rusak Karena Sampah". Berita (online), Edisi 20 Maret 2021. Tersedia dari: https://www.merdeka.com/peristiwa/wayankoster-akui-alam-bali-rusak-karenasampah.html.

Paramita, Ida Bagus Gede dan I Gede Gita Purnama Arsa. (2020). "New Normal bagi Pariwisata Bali di Masa Pandemi Covid-19". Pariwisata Budaya: Jurnal Ilmiah Pariwisata Agama dan Budaya, 5(2), Tersedia dari: DOI:

http://dx.doi.org/10.25078/pba.v5i2.1723

Perda Provinsi Bali Tentang Kepariwisataan Budaya Bali No. 2 Tahun 2012

Sugihamretha, I Dewa Gde. (2020). "Respon Kebijakan: Mitigasi Dampak Wabah Covid19 Pada Sektor Pariwisata Kementerian Perencanaan Pembangunan Nasional/Bappenas Republik Indonesia". The Indonesian Journal of Development Planning Volume IV, No. 2 - Juni 2020.

Suryahadi, Asep et al. (2020). The Impact of COVID-19 Outbreak on Poverty: An Estimation for Indonesia. SMERU. Working Paper. Jakarta: The SMERU Research Institute.

Suryani, Anih Sri. (2020). "Dampak Pandemi Covid-19 Terhadap Lingkungan Global". Pusat Penelitian Badan Keahlian DPR RI Jakarta. Kajian Singkat Terhadap Isu Aktual dan Strategis. Vol. XII, No. 13/I/Puslit/Juli/2020

Undang Undang No. 10/2009 tentang Kepariwisataan

Yakup, A. P. (2019). Pengaruh Sektor Pariwisata Terhadap Pertumbuhan Ekonomi di Indonesia. Universitas Airlangga.

Wirateja, Anak Agung Bagus. (2014). "Penanganan Dampak Perkembangan Pariwisata Dalam Aspek Lingkungan Fisik, 
Sosial, Ekonomi dan Budaya Bali" (Suatu Tinjauan
Pustaka).
FORUM
MANAJEMEN, 12 (2), Tahun 2014. 